\title{
APONTAMENTOS SOBRE A FORMAÇÃO DO PENSAMENTO JURÍDICO MODERNO
}

\author{
Sergio Guedes Martins ${ }^{1}$
}

\section{RESUMO:}

$\mathrm{O}$ artigo, com base em pesquisa bibliográfica, aborda momentos específicos na trajetória histórica europeia, como a recepção do direito romano nos séculos XI-XII, para indicar estruturas chaves no desenvolvimento do pensamento jurídico da modernidade, seu desenvolvimento nos marcos da teologia cristã e sua reapropriação posterior pela racionalidade científica moderna. Estruturas que concorrem para a transformação do direito num conhecimento instrumental, de apoio e profunda cumplicidade com o projeto político da modernidade.

Palavras-Chaves: Modernidade; Racionalidade; Direito Romano; Idade Média; Contratualista.

\section{NOTES ON THE FORMATION OF JURIDICAL THOUGHT MODERN}

\begin{abstract}
:
The article, based on bibliographical research, addresses specific moments in the European historical trajectory, such as the reception of Roman law in the XI-XII centuries, to indicate key structures in the development of legal thought of modernity, its development within the framework of christian theology and its reappropriation by modern scientific rationality. Structures that compete for the transformation of law into instrumental knowledge, support and deep complicity with the political project of modernity.
\end{abstract}

Keywords: Modernity; Rationality; Roman law; Middle Ages; Contractualist.

\section{Introdução}

O presente texto é fruto de reflexões sobre a estruturação do pensamento jurídico moderno. Busca a partir da leitura de obras que se debruçaram ou tangenciaram o tema, sistematizar ideias que demonstram como nosso pensamento jurídico contemporâneo é profundamente influenciado por debates de ideias presentes em momentos marcantes da história europeia, sobretudo a Idade Média, como processo de hegemonização da verdade científica, isto é, o processo de colonização de racionalidades positivas e emancipatórias, representado pelo surgimento de uma concepção de ciência moderna.

O Direito, nesse processo, experimentou perdas e ganhos, e se modificou, principalmente com a perspectiva monopolizadora da verdade científica. Já no dizer de Santos (2007), suas forças emancipatórias são podadas e remodeladas conforme a perspectiva moderna, num processo de absorção do pilar da emancipação pelo pilar da regulação.

A emergência da Modernidade enquanto paradigma dominante ganhou força e suporte ideológicos, uma vez que o direito veio proporcionar um controle social bem mais sofisticado do que até então cumprira em épocas passadas. Santos (2007) fala-nos da transformação do saber jurídico num conhecimento instrumental capaz de vincular a conduta

\footnotetext{
1 Possui graduação em Direito pela Universidade Federal do Pará (2003) e mestrado em Direito pela Universidade Federal do Pará (2009). Professor Assistente da Universidade Federal do Oeste do Pará-UFOPA.
} 
humana, isto é, vincular ações na perspectiva de construção e reprodução do modo de vida moderno capitalista.

Sendo assim, segundo o autor, o Direito amolda-se a uma "pauta" moderna, ao ponto de transformar-se em um conhecimento instrumental, de apoio e profunda cumplicidade com o projeto político da modernidade que se afirmava no mundo:

Ao direito moderno foi atribuída a tarefa de assegurar a ordem exigida pelo capitalismo, cujo desenvolvimento ocorrera num clima de caos social que era, em parte, obra sua. O direito moderno passou, assim, a constituir um racionalizador de segunda ordem da vida social, um substituto da cientifização da sociedade, o esartz que mais se aproximava - pelo menos no momento - da plena cientifização da sociedade que só poderia ser fruto da própria ciência moderna. Para desempenhar essa função, o direito moderno teve de se submeter à racionalidade cognitivo-instrumental da ciência moderna e tornar-se ele próprio científico (SANTOS, 2007, p. 119-120).

A perspectiva colocada por Santos (2007) de que o Direito se torna um saber instrumental, o garante de uma ordem, um pilar de sustentação do projeto político da modernidade, nos permite inferir também que isto se trata, em verdade, de uma reapropriação da racionalidade própria ao saber jurídico. Uma racionalidade forte, densa, que conseguiu aportar à Europa da nascente modernidade através de um longo e vigoroso processo de redescoberta deste saber da antiguidade clássica, que proporcionou continuidades e rupturas, conformando o que chamamos hoje de pensamento jurídico moderno.

Mas uma observação se faz necessária aqui. É preciso ficar claro que o direito, assim como outros saberes da humanidade, está sujeito ao jogo de interesses, à conivência dos poderes de época na sociedade. Como afirma Gadamer (2004, p. 51): "As ciências do espírito são colocadas a serviço dessas tendências, são avaliadas pelo significado que seus conhecimentos sociais, políticos, religiosos prestam ao poder vigente". Por isso é difícil pensar que somente na modernidade o direito tenha se prestado a uma tal função de garantir uma ordem, um status quo. O que vale dizer que a corrupção da razão não é, de todo modo, um privilégio do saber jurídico, é uma experiência humana, sobretudo humana.

Assim, na Roma Antiga, como possivelmente na Grécia também o foi, o Direito serviu como garante de uma ordem, e de igual modo a sua apropriação pela igreja na Idade Média, como também pelo Estado Absolutista. E por isso não é uma novidade moderna o fato de o Direito vir a cumprir um papel fundamental na manutenção da hegemonia modernidadecapitalismo. O Direito em si, não "precisava" tornar-se científico para cumprir tal papel, posto que em dada medida já o cumpria sem necessariamente está afeito à racionalidade científica moderna. Era um movimento de emergência, que cuidava de desvencilhar este conhecimento do manto sagrado e teológico, ou seja, o Direito comum da Idade Média, que sofreria uma guinada histórica a partir da releitura do direito romano feita a partir do século XII, que marca o início do processo de reapropriação da sólida racionalidade jurídica dos antigos.

Curiosamente o direito moderno pode ser explicado mais por elementos próprios da Idade Média do que necessariamente por acontecimentos que marcam a modernidade, como as ideias iluministas que apregoavam uma negação do passado. E por isso, é mais apropriado falarmos de que a conjuntura de redescoberta do direito antigo nos séculos XI-XII, levará para modernidade uma sólida base dogmática, um saber profundamente interpretativo vinculado ao texto escrito, enfim, que padecerá com o processo de colonização científica, levado a efeito pela racionalidade instrumental moderna.

Assim, na passagem para a Idade Moderna, temos a perspectiva forte de um Direito que se desafeta dos laços comunitários, desvencilha-se do senso comum, faz pouco caso da 
autoridade da tradição. Opera com firmeza uma sistematização que culminará com o movimento de codificação experimentado na Europa; e não seria demais afirmarmos que, em termos teóricos, teremos somente no século XX a paradigmática obra de Kelsen, como um dos momentos marcantes desta trajetória que cuidou de tornar o direito um conhecimento livre de entraves comunitários, e vale dizer: do senso comum, da tradição, em certo sentido que não é objeto deste artigo - isto quer dizer também livre da ética, da moral, da política.

\section{$2 \mathrm{O}$ diálogo com a Tradição Medieval}

Como dito, o desempenho de uma função instrumental mais sofisticada na modernidade, por assim dizer, deu-se ao custo da submissão do Direito à racionalidade cognitivo-instrumental da ciência moderna. Daí porque a transformação da ciência moderna em força hegemônica e força produtiva fundamental, e a transformação do Direito moderno num direito estatal e científico são faces do mesmo processo histórico (SANTOS, 2007, p. 120).

Três momentos guardam relevância para esta reapropriação do direito pela modernidade. O principal de todos é a chamada recepção do direito romano, espécie de releitura do direito romano ocorrida nos séculos XI-XII. Não menos importantes são as teses do direito natural racional e as teorias do contrato social ${ }^{2}$.

$\mathrm{Na}$ tradição medieval encontramos boa parte da formação e afirmação do pensamento jurídico moderno. Segundo Gilissen (2003, p. 244) em termos da evolução do direito público e privado da Europa Ocidental, não há solução de continuidade entre a Idade Média e a Época Moderna ${ }^{3}$, e isto é bastante significativo, posto que revigora a idéia de que há elementos que permanecem como informadores da cultura jurídica moderna, mas que são profundamente atingidos pelo emergir da modernidade, e assim reapropriados pela racionalidade própria do cientificismo.

Encontraremos na Idade Média - a quem por tanto tempo se imputou o fato de guarnecer um modelo de pensamento obscuro, pouco criativo, em trevas, de completo aniquilamento do que é racional - entre os séculos IX e XIII, segundo Alceu Amoroso Lima (2001), uma condensação ou integração de todo corpo jurídico produzido pelos romanos e os padres da igreja. É neste período que o direito se apresenta à sociedade em seu âmbito mais extenso, segundo o autor.

$\mathrm{O}$ argumento de Lima é de que esta integração revela uma concepção de unidade do direito que pode ser vista tanto na sociedade quanto na doutrina. De um lado, a lei era o princípio que dava consistência política ao direito - a vida social estava regrada minuciosamente: "Vida política, vida social, vida literária, vida econômica - tudo era objeto da mais estrita subordinação a preceitos legais, a tradições, a costumes" (LIMA, 2001, p. 82). Segundo o autor, o direito era uma coordenação da sociedade ${ }^{4}$.

\footnotetext{
${ }^{2}$ Estes elementos são apontados por Boaventura de Sousa Santos em sua análise das características originais da tensão entre regulação e emancipação no direito moderno, e aqui são tomados como uma espécie de roteiro para nossa análise.

${ }^{3}$ Continuando sua explanação afirma o autor: "Já pelo contrário, existirá uma ruptura bastante brutal entre os tempos modernos e a época contemporânea, em consequiência das transformações políticas e sociais resultantes da Revolução Francesa do fim do século XVIII". Cf. LIMA, A. A. introdução ao direito moderno. 2001. p. 244.

${ }^{4}$ Tal era o nível de ordenação, limitação, regramento, em toda parte, que uma das características do movimento antimedieval moderno será a oposição forte ao poder da autoridade, como afirma Lima: "Em nome do livre exame das Escrituras, contra a Autoridade na interpretação dos textos sagrados. Em nome da soberania nacional, contra a autoridade espiritual do Papado. Em nome da liberdade cogitativa, contra as regras, lógicas e metafisicas da Escola". Idem, p. 82.
} 
De outro lado, o princípio da hierarquia dava a tônica de unicidade no âmbito da doutrina jurídica - no período medievo um vasto emaranhado de normas convivia no meio social, mas as duas principais fontes do direito eram o direito natural e o costume, que por sua vez "só podia ser considerado como lei quando não se colocava em oposição àquele" (LIMA, 2001, p. 86). Portanto, o conceito hierárquico era encontrado no direito natural, segundo o autor. A lei natural para São Tomás de Aquino era a lei eterna, a lei revelada aos homens pela infinita graça divina, posto que a razão humana, imperfeita por sua natureza pecaminosa, não era capaz de apreender devidamente sequer a manifestação indireta desta lei, e "Por isso, ele revela um núcleo básico de normas, de conteúdo não só religioso, como também moral e jurídico por intermédio das Escrituras [...]A esta lei ele chama lei divina ou lei revelada". (GALLUPO, 2002, p. 54).

Nesse sentido, o direito medieval se caracterizará por seu forte laço comunitário, um direito que apesar da forte presença teológica - começo e fim da intelecção jurídica medieval - consegue conviver com a riqueza dos costumes sociais. Estes tinham força de lei, pois emanavam do seio social. Segundo Lima (2001), o Direito não ser imposto, mas sim nascer da própria comunidade.

A sociedade medieval, portanto, estava profundamente penetrada da idéia de lei, que exercia sobre ela uma supremacia completa. $\mathrm{O}$ direito era a base do organismo social, dele nascendo espontaneamente como elemento nativo da própria natureza da sociedade e do homem (LIMA, 2001, p. 89).

Esta concepção integral do direito, que foi traçada pelas reflexões filosóficas dos gregos, desenvolvida pelos romanos e completada no âmbito religioso pelos Padres da Igreja, não sofreu nenhuma interrupção radical senão no momento de fundação da escola de Bolonha (LIMA, 2001, p. 100). Este argumento é sustentado por uma visão de continuidade da Idade Média, e que traz a ideia de que o estudo sistemático do direito nunca desapareceu da Europa ocidental.

Contudo, tal continuidade não representa uma negação das vicissitudes históricas, antes quer dizer que não houve interrupções no desenvolvimento da ars juris de um período ao outro, e revela sim a retomada que fazem os medievos de algo que os romanos antigos aportaram para a posteridade: o seu forte pensamento jurídico. Cuja leitura feita pela igreja dará conta de firmar o aparecimento do corpus canônico que marcará a escolástica.

Esta recepção foi tão relevante para sedimentação de uma concepção jurídica que o Direito Canônico foi o único direito escrito durante quase toda a Idade Média. Ao lado deste também figurava um direito laico consuetudinário e "enquanto as primeiras redações de costumes remontam a época não muito anterior ao século XIII, o direito canônico foi redigido, comentado e analisado a partir da Alta Idade Média" (GILISSEN, 2003, p. 134). Se importante para sistematização da dogmática escolástica, também este fato nos permite inferir que neste momento já há uma forte tradição interpretativa presente na vida jurídica medieval.

Esta sistematização começa a partir do século XII, e será capaz de se estender até nossos dias, ainda que não possua a força vinculativa nos espaços não eclesiásticos. Sua decadência é assinalada no século XIV, com o Grande Cisma do Ocidente. Mas de qualquer forma cuidará de estabelecer um grande domínio inclusive em temas da vida privada, durante vários séculos, mesmo para os laicos, como demonstra Gilissen (2003, p. 134):

Qualquer litígio relativo ao casamento ou ao divórcio foi da competência da jurisdição eclesiástica a partir do século VIII. Foi assim em França até ao século XVI, e na Bélgica até ao século XVIII. Por isso, o direito canônico está na base de numerosas disposições do direito civil moderno. 
Desta maneira é que se estabeleceu de forma contundente um mundo jurídico medieval altamente forjado numa combinação de elementos da cultura jurídica romana, da filosofia helenística e do próprio cristianismo. Sendo que sucessivas leituras vão-se sobrepondo, demonstrando que há uma intermediação da escolástica no diálogo entre o pensamento clássico e a tradição moderna, como afirma Weyl (2008, p. 60):

No umbral da formação do direito moderno, o que está em questão, fundamentalmente, é mais fundamentação cristã do direito do que a fundamentação metafísica do direito à qual esta é filiada. A relação da filosofia do direito moderno, em seu nascedouro, não se realiza diretamente com a tradição clássica, mas com a apropriação escolástica do pensamento antigo.

Estas ideias vão ao encontro do que diz Michel Villey (2005), para quem encontramos uma espécie de história pré-moderna nos séculos XIV e XV, na própria doutrina escolástica e que há uma raiz do pensamento moderno que não temos condições de buscá-la senão em suas fontes filosóficas antiga e medieval. O Autor faz clara referência a duas características marcantes do pensamento moderno que remontam à Idade Média: a laicidade e o individualismo.

Nas várias "Idades Médias" que existiram, no período compreendido entre os séculos XI e XVII, surgiram duas grandes escolas: a humanista e a integrista. A primeira destas correntes foi mais receptiva à então chamada filosofia profana, atingindo seu auge com a obra de São Tomás de Aquino. A obra de Aristóteles foi recepcionada na Idade Média por intermédio de São Tomás de Aquino, que lhe imprimiu uma leitura cristã acima de tudo, firmando uma ideia do Direito que fazia da fé o seu ponto de partida.

Mas sua contribuição fundamental foi, sobretudo, permitir-se aos estudos de textos profanos, revelando em certa medida um "respeito à razão profana". Como diz Villey (2005, p. 181): "teve a audácia de restaurar abertamente a autoridade dos filósofos e dos sábios do mundo pagão, principalmente a de Aristóteles, e de afirmar sua confiança na dialética profana".

Com a modernidade esta forma de conhecimento primeiro para os escolásticos (a fé), dá lugar paulatinamente à confiança na razão, mas o passo fundamental no sentido de romper os limites dos estudos bíblicos foi dado na Idade Média. Esta substituição contribuirá para a afirmação de um pensamento jurídico de caráter mais racional se desvencilhando da ortodoxia de matriz tomista.

A segunda corrente foi de certo modo mais intimamente ligada à tradição cristã, encontrando em Santo Agostinho uma grande referência. Manteve-se viva, mas de certa forma secundarizada por conta da pujança da síntese tomista. Mas no século XIV é reanimada pelos estudos de Duns Escoto e de Guilherme de Ockham.

$\mathrm{O}$ individualismo é um dos principais traços do pensamento moderno, contrapondose às concepções então dominantes da Idade Média, assim como da tradição clássica, sobretudo em Aristóteles (VILLEY, 2005, p. 176), que possuíam, por assim dizer, uma face mais comunitária.

\footnotetext{
${ }^{5}$ Este termo é usado por Michel Villey para designar as distinções existentes no longo lapso de tempo que representa a Idade Média, e que, portanto, não se trata de uma época estanque que comporta uma única maneira de pensar. Trabalha com uma divisão de certa forma clássica que compreende os seguintes períodos: alta Idade Média, dominada pela ditadura da fé e das sagradas escrituras; e depois do século XI-XII um período mais privilegiado pelo embate de ideias.
} 
Michel Villey (2005, p. 180-181) insiste que estas duas correntes de pensamento contribuíram para a construção do pensamento jurídico moderno, pois vê em São Tomás aquele que retorna ao clássico pensamento grego, principalmente Aristóteles, e empreende uma obra que reabilita a razão em meio ao império da fé, contribuindo com a laicidade. $\mathrm{E}$ aponta Guilherme de Ockham da escola nominalista como um formulador da principal característica do direito moderno: o individualismo. Estes traços possuem suas origens na escolástica medieval, ainda que dissociados. Como afirma o autor:

a laicidade, o respeito à razão profana, vêm da escola de são Tomás; o individualismo e suas consequências, o positivismo jurídico, o conceito de direito subjetivo surgem da escola rival do começo do século XIV, da escolástica franciscana e, sobretudo, do nominalismo de Guilherme de Ockham (FASSÓ apud VILLEY, 2005, p. 179).

De todo, a Idade Média será marcada por um pensamento jurídico comum. Obviamente que ordenado a partir da fé, mas não sem maior vigor e rigor em seus institutos. A forte racionalidade do direito é perceptível, e exemplo disso é a formulação do direito canônico, que como nos informa Gilissen (2003, p. 135) se constituiu em objeto de muitos estudos doutrinais, muito antes do direito laico, vindo a conformar uma espécie de ciência do direito canônico.

3 Direito Romano: um necessário aporte para a Modernidade

Enquanto a antiguidade grega e egípcia experimentava instituições mais sólidas do ponto vista jurídico - que ajudavam na conformação das bases de importantes civilizações como o foram tais povos nos séculos VI e V a.C. -, a Roma da mesma época estava submetida a um regime arcaico, de uma sociedade maciçamente rural, de regime clânico, e, por conseguinte, sem maior complexidade do ponto de vista jurídico, só encontrando considerável evolução apenas nos séculos I e II de nossa era (GILISSEN, 2003, p. 80).

Curiosamente, nos 22 séculos seguintes, estabeleceu-se como uma das maiores contribuições históricas que a civilização romana legou à posteridade. E assim, se é verdade que encontramos nessa "permanência" do direito romano a resistência de uma tradição cultural, que legou ao mundo uma influência espiritual das mais positivas, como forte pensamento racional que foi, conforme Weyl (2008, 61-62), não se pode dizer que foram estas características que se ofereceram efetivamente à posteridade medieval e mesmo à modernidade. Isto porque, já no período que remonta ao processo da própria formação da Idade Média, se coloca a questão de saber qual direito foi recebido ou "em qual período do entrecruzamento de suas instituições públicas com o seu direito privado foram engendradas as instituições jurídicas da Europa Ocidental na Idade Média" (WEYL, 2008, p. 74).

Segundo Weyl (2008), o momento de declínio da cultura romana (período tardio) foi caracterizado no campo jurídico pela radical transformação das instituições públicas romanas, marcadas, a partir de então, por um forte predomínio monárquico e uma crescente codificação e centralização da produção normativa por esse mesmo poder, num claro presságio do que viria a ser os movimentos pela codificação do direito na posteridade.

Esta época também era caracterizada por uma aproximação do cristianismo com a filosofia, onde se verifica o começo do predomínio eclesiástico na formação cultural do ocidente, pois se passa a um período em que a Igreja ressignifica a tradição filosófica antiga absorvendo seus elementos numa perspectiva teológica (Weyl, 2008, p. 75). Seguindo o autor, o direito romano perde sua qualidade, e enquanto sistema erudito serve de base para o direito canônico; enquanto cultura, empresta concepção metodológica aos direitos dos povos 
germânicos; e por fim, enquanto normas de direito positivado sobrevive por compilações de direito vulgar, muito adequada a interesses monárquicos então emergentes (WEYL, 2008, p. 77). Portanto, pode se afirmar que a cultura jurídica romana já sofre um certo obscurecimento na própria passagem da antiguidade ao período medievo, que lhe podou características de sua formação.

Ora, se podemos dizer que este aporte para o mundo medieval da cultura jurídica romana - considerando inclusive a maneira fragmentada como se foi dando este contato - foi uma primeira recepção do direito romano, encontraremos uma "nova" recepção desta pujante cultura, ocorrida no século $\mathrm{XII}^{6}$, que apesar de haver divergência quanto à inserção sociológica ${ }^{7}$ deste fenômeno na história europeia, trata-se, como bem o afirma Santos (2007), do fator mais importante na formação jurídica moderna ocidental.

Esta redescoberta do direito romano, ainda no contexto do século XI, foi capaz de resgatar elementos importantes desta cultura, sobretudo o fazer normativo da época clássica. Esta redescoberta foi subordinada (WEYL, 2008, p. 78) à visão medieval cristã que pautava o direito como uma técnica dogmática e exegética. Deve-se compreender com isto que houve uma reorientação do direito - e isto quer dizer de seu fundamento - em direção ao sagrado, e com isso um aprofundamento da cultura dogmática, que já se apresentava bastante desenvolvida no direito canônico. E a partir deste momento já se mostra uma característica importante que atravessará para a modernidade, isto é:

O texto atinge um status de substância, uma significância de verdade, dada a natureza divina que se lhe atribui. Sob esse aspecto, a retomada do direito romano clássico contrapõe a erudição da técnica e dos escritos jurisprudenciais ao fundamento cristão, mas não à postura dogmática. Esta é adaptável (mantida a centralidade do texto: O Corpus Juris Civilis no lugar da Sagrada Escritura, dada a revalorização da razão, de que é tecida a criação jurídica romana); equiparado à razão, o corpus juris civilis - ratio scripta ocupou o lugar antes reservado à Escritura na emergente ciência do direito (WEYL, 2008, p. 78).

A literatura jurídica romana será vista através do fundamento cristão da sociedade medieval, e por isso mesmo o texto ganha em importância e substancialidade. Não seria de todo absurdo pensarmos que esta atitude perante o texto será revigorada e reapropriada na modernidade, que terá na legislação sua principal fonte jurídica, e as consequências daí advindas serão enormes, como, por exemplo, a significativa aposta na literalidade da lei para dizer o que é o direito.

E por fim, seguindo a argumentação de Weyl, demonstrando que a modernidade receberá algo mais do período medieval, tal subordinação ao texto cuidará de estabelecer uma atitude frente a norma, lhe reconhecendo uma validade intemporal. Tais características (subordinação à visão especular do medievo, subordinação ao texto e validade intemporal da norma) configuram um aporte fundamental para a modernidade.

Assim, temos que a dogmática fala de um "outro lugar", não mais pautada apenas nas escrituras, mas agora a partir de um corpo de compilação identificado com uma racionalidade

\footnotetext{
${ }^{6}$ Para Santos trata-se de um momento de manifestação da tensão entre regulação e emancipação.

7 Santos destaca as teses de Harold Berman, para quem foi importante neste período a revolução papal e o novo direito canônico que deu origem; assim como as de Michael Tigar e Madeleine Levy que acentuam a adaptação do direito romano aos interesses da burguesia; e, ainda, a de Fernando Braudel para quem este período representa o verdadeiro Renascimento. Cf. SANTOS, 2007, op. cit. p. 121.
} 
própria, e por isso mesmo enriquecendo a técnica jurídica e possibilitando a retomada do Direito como uma ciência.

Mas esta integralidade, característica do direito medieval, sofre uma inflexão a partir do século XII que marca os primeiros passos da formação de uma ciência jurídica desvinculada das presilhas cristãs. E isso foi possibilitado em grande medida pelas cidades italianas ${ }^{8}$.

É que no Império Bizantino (Europa Oriental), o direito romano foi aplicado durante toda a Idade Média e, segundo afirma Gilissen (2003), algumas partes da Itália sempre mantiveram contato com Bizâncio durante a chamada Alta Idade Média. O mesmo não ocorrendo no lado ocidental, uma vez que não há notícias de estudos de direito romano na França, Inglaterra ou Alemanha por esta época. Na Itália, entretanto, subsiste traços da cultura jurídica romana de maneira marcante, inclusive em estudos nas escolas de Roma e Ravena (GILISSEN, 2003, p. 341).

Este ensino era bem diferente do que até então fora, porque não haviam escolas de direito, e o ensino, monopolizado e associado ao ensino eclesiástico, dava-se em mosteiros e catedrais, compreendendo uma parte dentro do seguinte esquema: Trivium (gramática, retórica e dialética) e o Quadrivium (aritmética, geometria, música e astronomia). O direito era ensinado dentro da retórica e da dialética.

Mesmo o direito romano não desaparecendo totalmente na Itália, houve uma espécie de renascimento ${ }^{9}$ deste direito a partir do século XII, muito por obra de professores de Bolonha. Esse movimento estava interessado num trabalho mais científico em cima dos textos antigos e o faziam com maior rigor metodológico (GILISSEN, 2003, p. 341).

Em torno destes forma-se a Escola de Bolonha, que ficou conhecida por seu método da glosa. Valendo-se de breves explicações de frases e até de textos inteiros, fosse nas entrelinhas ou nas margens dos manuscritos, procuraram estudar sistematicamente os textos de direito romano das épocas clássica e bizantina, perfazendo um estudo do direito enquanto ciência, afastando-se do quadro do Trivium, ensinando e estudando um direito romano de maneira sistemática, coerente e completa.

A escola de Bolonha perdeu um pouco da centralidade nos estudos romanistas no século XIII. Outras escolas acabaram sendo fundadas, como por exemplo, a Escola de Orleães, que se voltando contra o método dos glosadores, alguns professores ligados à igreja, buscaram uma renovação dos estudos do direito romano. O mesmo ocorrendo no final do século XIII, quando foi fundada a escola dos Pós-glosadores, que por sua vez reagiam ao método demasiado analítico dos glosadores, buscando novos métodos de interpretação dos textos romanos. Estes influenciaram as universidades italianas até princípios do século XVI. Nos pós-glosadores seu método, segundo nos informa Gilissen (2003, p. 346), foi inspirado pela dialética escolástica: "a nova escola põe a tónica (sic) sobre a necessidade de examinar os textos de direito romano no seu conjunto e de retirar deles princípios gerais, a fim de os aplicar aos problemas concretos da vida corrente".

\footnotetext{
${ }^{8}$ Afirma Michel Villey: "no norte da Itália, no século XI, deu-se o ressurgimento das cidades e do comércio: há trocas, contratos, fortunas individuais. Precisa-se de medidas estritas os limites das posses e das consequências dos contratos, de fixação do meu e do teu. Tampouco os grandes Estados poderão, no longo prazo, prescindir da definição das competências de seus funcionários. Para isso, porém, só se dispõe do direito romano para fornecer alguma assistência. É então temporariamente refugiado sob o pavilhão do Império cristão, mas em oposição profunda ao agostinismo jurídico, que se inicia o renascimento bolonhês". Cf. VILLEY, 2005, op. cit. p.120.

${ }^{9}$ Tal renascimento é parte de um contexto geral de renascimento intelectual de cunho filosófico e literário, mas também se cogita da hipótese de que o característico desenvolvimento comercial das cidades do norte da Itália, como dito, pode ter contribuído para um maior interesse pelo estudo de um sistema jurídico mais desenvolvido.
} 
Ao final do período medieval o estudo do direito romano volta-se cada vez mais para fins práticos. Os pós-glosadores procuraram adaptar o direito romano ao medieval, e então, no fim do século XV e início do XVI, os estudos de direito romano são objetos de severas críticas. John Gilissen (2003) afirma que neste período há um novo renascimento do direito romano $^{10}$. Influenciados pelo Humanismo os romanistas procuram estudar o direito romano por ele mesmo, "num fim puramente científico e abstraindo de qualquer aplicação ao direito moderno" (GILISSEN, 2003, p. 348).

A escola humanista se propunha fazer um retorno aos textos jurídicos romanos e bizantinos livres de quaisquer comentários, num trabalho vigoroso onde já aparece uma influência da nascente filologia. Tinha por objetivo ainda explicar os textos romanos com base em outros documentos romanos, sobretudo históricos e literários. Não menos importante era a intenção de se estabelecer o sentido original e o verdadeiro alcance das regras jurídicas nos limites do próprio direito romano, e ainda buscar uma reconstrução do sistema romano numa linguagem profundamente marcada pela erudição clássica do latim.

De certa forma esta adesão às incipientes concepções metodológico-científicas modernas pouco a pouco estabeleceu um corte, aproximando o declínio destes estudos de tradição romanista. A História ${ }^{11}$, por exemplo, em seus primórdios mostrou-se ligada a uma concepção heurística e documental, não totalmente uma ciência, mas uma narrativa que dava conta de grandes acontecimentos militares, crônicas de reis, vidas de santos, etc. Com a ciência moderna, os métodos e procedimentos de ciência positiva são adotados como modelos adequados para obter-se conhecimento. Com isso, a História (e sem dúvida os estudos do direito) se envolve com tais pressupostos, tornando-se, no final do século XVII, uma ciência. Segundo afirma Michel Villey (2005), estas mudanças foram integrais na Alemanha do século XIX.

O passado foi colocado como o campo apropriado aos estudos da história, o que em certa medida foi capaz de estabelecer um olhar sobre um passado ensimesmado, um passado sem mais, como aquilo que está consumado. A história teria se tornado, assim, uma ciência do factum. A partir desta concepção, a história, imitando o fazer das ciências mecânicas, tinha como função buscar as causas das mudanças no passado, retratava gêneses, evoluções, descrições em grandes obras de síntese ${ }^{12}$. Teremos assim uma história científica marcada pelo

\footnotetext{
${ }^{10}$ Gillissen aponta os séculos XV-XVI como o período em que realmente há uma efetiva recepção do direito romano, posto que foi alçado ao posto de direito subsidiário na maior parte dos países europeus no lado ocidental. E esta recepção é mais forte no sul da França, assim como na Itália e Espanha do que nos países do Norte da Europa Ocidental. Neste sentido escreve Gilissen: "Chamar-se-á por isso ao Sul da França os "pays de droit écrit' por oposição ao Norte, designado 'pays de droit coutumier'. Na realidade, o direito do Sul é consuetudinário como o do Norte, mas está muito mais próximo, pelas suas origens, do direito romano que renasce". Cf. Gilissen, op. cit., p. 241.

${ }^{11}$ Fazemos questão de citar os estudos de História, pois vemos este saber bastante envolvido na base de tantas especialidades não só do conhecimento científico, mas de outros logos. Os estudos sobre História, que envolve uma competência filosófica fundamental entre os alemães, marcará profundamente o estudo do Direito, mas, sobretudo, proporcionará um terreno fértil para o exsurgir de uma nova hermenêutica, principalmente com as contribuições de Schleiermacher e Dilthey, autores a partir dos quais toda uma tradição, de matriz alemã, aportará ao mundo.

${ }^{12}$ Vale a pena também conferir o texto de Gadamer sobre o problema da história na filosofia alemã, que numa clara contraposição a essa ideia de história como transformação sucessiva, ascensão e queda de povos, afirma o seguinte: "Os gregos, os primeiros a configurar a concepção ocidental de mundo, não consideraram essa ascensão e queda como a essência da existência (do ser homem), mas como o que provém de alguma outra coisa, que sempre permanece em toda mudança, por ser a ordem justa. $\mathrm{O}$ modelo, segundo o qual se pensava o ser humano, era a natureza, a ordem cósmica que se mantém e se renova num eterno retorno". Cf. Gadamer, H. G. Verdade e método II, 2004. p. 37-38).
} 
culto aos fatos, nos dando uma visão progressista da evolução, de saltos qualitativos em direção ao futuro sempre mais desenvolvido e melhor que o passado.

De igual modo tal mudança atingirá, segundo Villey (2007), os estudos romanistas, havendo um total abandono dos estudos do direito romano e jurisprudência clássica, ocorrendo uma especialização das análises na história da Roma arcaica, na decifração da lei das XII tábuas, ou ainda em pesquisas sobre direitos cuneiformes. A idolatria pelos fatos é uma característica marcante das ciências "experimentais modernas". Esta característica é profundamente conformada pela idéia da ontologia nominalista, a qual preconiza como reais tão somente coisas singulares, sem considerar as devidas relações existentes entre tais coisas. Como afirma Villey (2007, p. 28):

Quanto às relações, às hierarquias, à ordem geral em que estão dispostas essas coisas singulares, elas não teriam realidade fora de nossos discursos e de nossa mente: tratar-se-ia apenas de signos, gerados livremente pelo homem que os remaneja a seu bel-prazer para melhor calcular as coisas reais singulares.

Santos (2007) relata que durante o período da recepção do direito romano nos séculos XI-XII, a Europa passava por sérias transformações de toda ordem, e com base em Wieacker, afirma que a recepção do direito romano era resultado de uma convergência única de interesses econômicos e culturais. E, ainda, a tensão emancipação-regulação, constitutiva dessa recepção, pende para esta última quando os interesses da classe social, que desenvolverá um projeto cultural, político e econômico de emancipação social, são finalmente conquistados. Deste momento em diante, as condições especificas da época que permitiam objetivos emancipatórios nas atividades de regulação social, mudaram drasticamente.

Quando se alteraram as condições específicas da época, as características do direito romano, tão reclamadas, num sentido mais nobre, por Villey, Lima, e mesmo por Weyl, transformaram-se em dispositivos atraentes para uma sobreposição da regulação em detrimento da emancipação. Processo, que, segundo Santos (2007, p. 123-124), irá culminar no século XIX com os Pandectistas, que fizeram do direito romano uma estrutura formal e hierarquizada de regras, a partir de um sistema rígido e lógico, e toda a tradição romana será condensada num formalismo técnico-racional, muito mais apropriado aos ditames modernos. E durante o período do capitalismo, do nacionalismo e do imperialismo, a regulação social se torna científica para ser maximizada, e, acrescentaríamos, para ter maior vigor vinculativo.

Concretamente a recepção do direito romano é um marco, sem dúvida, na história jurídica do ocidente, e constituiu as bases em torno das quais por muito tempo disputaram concepções sobre o direito, sendo, por fim, sedimentado uma ciência ligada ao texto legal

\section{0 direito natural racionalista e visão contratualista da sociedade}

A razão, a observação e a experimentação serão elementos importantes na constituição e fundação de uma nova boa ordem desprendida das amarras da escolástica, posto que o respectivo exercício desses elementos estará na base da racionalidade moderna. Esta boa ordem se forma segundo a lei da natureza, que fundamenta uma visão secularizada da regulação da vida coletiva e individual, pois "A concepção de direito natural, que dominou toda essa época, ia sofrer a repercussão desse naturalismo, que pouco a pouco substituía ao conceito do direito natural como reflexo no homem da lei eterna, provinda de Deus" (LIMA, 2001, p. 156).

A secularização do direito será a tônica na modernidade. Um movimento que, segundo a lição de Michel Villey (2005, p. 175), começa já em São Tomás de Aquino, agora é 
confirmado na obra de Hugo Grotius ${ }^{13}$ (1583-1645), o qual possui a versão mais elaborada desta doutrina.

Estabelece-se uma racionalidade que se assenta numa ética social que se emancipa da teologia moral, em que pese o laicismo, como bem mostra Villey, não representar necessariamente uma atitude antirreligiosa ${ }^{14}$. Basicamente defendia-se que o exercício da razão, além deste desprendimento total em relação à tradição, produziria também uma racionalidade universal e igualmente aplicável universalmente, numa clara resignação ao ditame cartesiano, segundo o qual um "efeito que seja universal exige uma causa universal e a causa dessa opinião não pode ser outra coisa senão o sentimento a que se chama o senso comum da humanidade" (GROTIUS apud SANTOS, 2007. p. 125).

Assim, para confirmar o exercício inebriante da razão, seu corolário metodológico: a experimentação. A recorrência à autoridade do passado passou a ser seletiva, e um espírito de desconfiança em relação a esta foi adotado como regra.

É uma tese em voga de que este direito natural racional desde os primórdios da Idade Moderna, caracterizado pelo embate entre a liberdade burguesa e o despotismo, tenha sido a fortaleza de idéias onde procuraram asilo tanto adeptos da liberdade como do absolutismo (BONAVIDES, 1972, p. 02), pois como afirma Santos (2007, p. 125): "o direito natural racionalista serviu para legitimar, quer o 'despotismo iluminado', quer as ideias liberais e democráticas que conduziram à Revolução Francesa”. Esta duplicidade comporta a tensão entre regulação e emancipação.

As forças emancipatórias deste direito natural racional, muito cultivado nas universidades a partir da retomada dos estudos romanistas, culminam com a ascensão ao poder da burguesia revolucionária francesa. Tratava-se de um espírito contestador que expressava interesses de grupos sociais que a todo custo opunham novos valores e crenças que iam de encontro com os resquícios do feudalismo aristocrático (WOLKMER, 2007, p. $30)$.

O direito na teoria de Grotius era visto como parte da vida coletiva, e, por conseguinte, de todos os grupos sociais em que ela se organiza (SANTOS, 2007, p. 126). Os pensadores racional-naturalistas acreditavam que o Estado jurídico se mostrava como a formulação teórica capaz de resguardar a liberdade ilimitada que o homem desfrutava em seu estado natural, numa sociedade pré-estatal, ou ainda fazer desta liberdade ter uma condição de precedência frente ao Estado, fazendo deste um servo do indivíduo, na expressão de Bonavides (2009, p. 02). Para os naturalistas modernos, importava em primeiro lugar organizar a liberdade no campo social, tarefa que não mais será secundarizada pelo Direito moderno.

A sistematização e a racionalização serão características marcantes do jusnaturalismo dos séculos XV e XVI, uma preocupação que se revela como uma das primeiras cumplicidades entre ciência moderna e direito, haja vista que a preocupação com o methodus, os schemata e a ratio combina-se com o espírito cientifico inaugurado por Galileu e Descartes (SANTOS, 2007, p. 126).

Em Gianbattista Vico e sua proposta de uma nova ciência, encontra-se a proposta de se chegar aos princípios da história tal qual Newton o havia descoberto em relação à natureza

\footnotetext{
13 Segundo Lima "Grotius é apresentado, pois, como o secularizador do direito, como o eliminador da fonte divina do direito, como o criador de um direito natural independente e humano [...] Grotius libertava-se do pensamento escolástico, marcava o fim da Idade Média, e o início do mundo moderno, para a ciência do direito, e elaborava esta em bases novas inteiramente livres, autônomas e racionais". (2001, p. 158)

${ }^{14}$ No entendimento de Michel Villey apenas posteriormente, em Espinosa e na filosofia do século XVIII, é que se notará esta ruptura com mais propriedade. Cf. VILLEY, op. cit., p. 176.
} 
(SANTOS, 2007, p. 127). Mas Vico estará consciente de que isto será impossível, posto que ciência histórica e a natureza jamais poderão compartilhar os mesmos princípios e métodos.

Em certa medida isso coloca Vico numa contraposição aos postulados cartesianos, uma vez que seriam incapazes de dar o tratamento adequado às questões sociais, e por isso recorre à filologia e ao direito para poder trabalhar adequadamente, e buscar princípios alternativos. Em Gadamer (2003) encontramos um Vico inserido numa tradição ininterrupta da formação retórico-humanista e precisava resgatar a validade daquilo que se mantinha conservado dessa tradição. O direito será um caso desses. Esta posição de Vico mostra como que o problema filosófico colocado pelas ciências do espírito à filosofia deve romper com a estreiteza que lhe é imposto pela discussão de método das ciências naturais (GADAMER, 2003, p. 54-69).

Para as ciências do espírito os estudos humanistas, aos quais Vico se vincula, ganham novo significado a partir da resistência que oferecem aos desígnios da ciência moderna, e segundo o autor de Verdade e Método as ciências filosóficas do século XIX devem sua vida peculiar à sobrevivência desse pensamento humanista. Remetido, em seu perguntar filosófico, aos estudos humanistas, Gadamer (2003) nos afirmará que em Vico encontraremos um ponto de referência nesse diálogo que as ciências do espírito devem travar com o humanismo.

Para finalizar, é interessante notar que em Gadamer podemos ver a face de Vico como representando também uma tensão outra: entre ciência moderna e estudos humanistas. O que pode ser visto no seguinte trecho: "Vico não se refere mais ao antagonismo com relação à 'escola', mas ao especial antagonismo com relação à ciência moderna" (GADAMER, 2003, p. 57).

Seguramente estas tensões que revelam em grande medida a procedente análise de Santos (2007), também dão conta de mostrar como a concepção de ciência atinge a ciência jurídica moderna, o que requer análises mais detidas, que terão desdobramentos outros que aqui não temos condições de levar adiante.

De igual forma temos na visão contratualista um importante passo rumo à transformação do direito em um saber caudatário dos desígnios da modernidade e seu paradigmático enredamento no projeto capitalista. É que nestas teorias contratualistas, se toma por base também o forte apelo que o espírito do direito natural possui e estabelece como norma. É o que fica claro na fala de Santos (2007, p. 129):

O que de novo existe nas teorias de Hobbes, Locke e Rousseau é o facto de todas elas serem fruto do debate sobre o direito natural racionalista, do qual, evidentemente, partem, e de se considerarem parte da nova ordem social e política e do novo método cientifico moderno de análise da realidade.

Cremos que isso remonta um pouco as bases ligadas à afirmação de um pensamento comprometido com a modernidade, e consequentemente ligado às pretensões de verdade da ciência moderna. E como o direito moderno se ergue em grande medida a partir dessas teorias contratualistas, sua ligação às pretensões científicas ficam mais evidentes.

Em Rousseau encontra-se uma formulação ligada aos parâmetros contratualistas, mas, ao mesmo tempo, contestadora e crítica em relação à ciência moderna, posto que esta não consegue dar respostas aos graves problemas éticos de sua época. Por isso, Santos (2007) vê em Rousseau o melhor exemplo da tensão dialética existente entre regulação e emancipação. Afirmando que a querela entre certeza e justiça, existente em Rousseau, remonta ao novo projeto de sociedade pelo qual o ser humano é moralmente responsável.

Para Rousseau a ideia de uma preexistência social em relação ao Estado, onde a liberdade reina absoluta, leva a crer que a passagem ao estado social é uma opção humana. E 
perante esta individual opção moral, como será possível a vida coletiva sob o estado social? O contrato social será a resposta manifesta do iluminismo, onde a vontade individual, que poderá ser boa ou má, sucumbirá diante da vontade geral que somente poderá ser boa (SANTOS, 2007, p. 130).

Se esta tensão dialética existente em Rousseau é importante, e envolve o acerto entre liberdade e vida coletiva, não menos importante é a ideia contratual que lhe abriga, e que aqui, pelo menos em nosso entendimento, sobressai-se como um pilar formador do direito moderno que se inscreverá até nossos dias como uma de suas principais características.

O contrato se mostra como um dos símbolos da nova configuração política da Europa a partir da Revolução Francesa, que muita contribuição trouxe para que o direito se transformasse em um braço forte deste projeto. Marca sobremaneira a ideia de vontade livre, e, sobretudo, atesta a autonomia da vontade como base para as relações comerciais em franca ascensão.

Para Wolkmer (2007) é uma exacerbação do individualismo que acaba por ocultar a desigualdade real existente na sociedade. Segundo o citado autor:

Esse pacto montado conforme a declaração de vontade das partes intervenientes é concebido para homens abstratos, livres e que estejam na condição de igualdade formal, realidade específica dos proprietários burgueses [...] os excessos do liberalismo contratualista não deixam de ser imperativos das novas conveniências políticas e das novas necessidades materiais da vida social burguesa (WOLKMER, 2007, p. 35).

Por fim, encontramos em Hobbes uma teoria que, primando pelas potencialidades da ciência para lograr uma ordem incontroversa, estabelece o Estado como um elemento fundamental na construção do moderno pensamento jurídico, posto que o voluntarismo estatal aparece em seus primórdios, isto é, a atividade legislativa que será monopolizada pelo Estado já mostra sua face remota na modernidade, pois para Hobbes "Em vez de ser o direito uma emanação da lei e em última análise de Deus, é a lei uma limitação do direito, e em última análise criação do Estado" (LIMA, 2001, p. 141).

Enquanto vemos em Rousseau uma soberania constituída num contrato feito por todos os membros da sociedade em favor desta mesma sociedade, em Hobbes o Estado, desde o momento de sua constituição estabelece a resignação como regra, a fim de que se busque a paz através da submissão absoluta dos súditos ao soberano. Como afirma Santos: "o pensamento de Hobbes transporta já as sementes da estatização como uma forma empobrecida da regulação moderna" (2007, p. 134). Vemos que as teorias contratualistas vêm a ser formulações que sedimentam as ideias próprias do direito racional natural, e entrecruzam os elementos emergentes da nova ciência, aliando elaborações tradicionais ao uso da observação, experimentação e da razão.

\section{Considerações finais}

Do pouco relatado neste artigo, pode-se inferir que as características mais marcantes do direito moderno já emergiam desde o século XI-XII, encontrando um desenvolvimento nos séculos XV-XVI e estabilizando-se nos séculos XVII-XVIII (GILISSEN, 2003, p. 244). Se podemos falar nestes termos, o direito enquanto saber articulador de uma racionalidade sedimentada numa prática interpretativa que remonta à antiguidade, é vítima do processo de colonização que a racionalidade instrumental científica moderna implementa no seu processo de hegemonização no mundo ocidental. 
Ao tempo em que é reapropriado, perdendo neste processo muito de seu caráter mais comunitário, por assim dizer, e também de suas forças emancipatórias, ganha em sistematização progressiva e passa assim a exercer um papel fundamental na garantia do status quo. Essa é uma face do direito que se mostra nova, emergindo com a modernidade, guardando muito de seu desenvolvimento antigo enquanto um saber prático, mas também se aproveitando de novidades advindas com a nova ciência, principalmente seu caráter mais sistematizador e ordenador geral da sociedade. O Direito passa a ser um sistema racional dedutivo que se diferencia significativamente da racionalidade que o caracterizou desde a antiguidade, sobretudo com os romanos. Como afirma Gallupo (2002, p. 56-57):

Desde o século XI, entretanto, não era mais a prudência (phrónesis) ou a comunidade (ethos) que orientavam, de modo imediato, o conhecimento do direito. Para conhecer o direito, era preciso conhecer os textos dos juristas romanos e, muitas vezes (sobretudo com os pós-glosadores), as glosas. Os textos não eram mais o resultado do pensamento jurídico, mas seu ponto de partida, sobretudo após o aparecimento da Litera Bolonienses, que passou a ser utilizada como texto escolar [...] e consequentemente, também como fonte para a decisão judicial.

Uma confusão entre lei e direito será a marca, por excelência, da juridicidade moderna. O movimento de codificação que atingiu a Europa em finais do século XVIII, em especial o Código Napoleônico, é um passo arrematador do processo de aprisionamento da atividade interpretativa jurisdicional clássica pelo modus interpretativo moderno, que é embasado nesta confusão entre texto legal e norma jurídica, que tem seu ponto de partida não na atividade criativa da interpretação, mas no texto legal, na lei, não apenas porque esta se constitui como a principal fonte do direito na modernidade, mas porque também se arvorou do poder de dizer o que é o direito, secundarizando a atividade interpretativa, e muitas vezes reputando a esta o desvirtuamento do direito, negando-lhe o papel fundamental que sempre teve.

Aliás, esta característica do direito na época moderna trata-se de uma tendência para a unificação legislativa, afinal, como dito, a "legislação torna-se por excelência a fonte viva do direito; tende a eliminar progressivamente o costume, que revoga ou suplanta" (GILISSEN, 2003, 247). Sendo um dos objetivos mais visados por soberanos absolutistas, a unificação do direito seria usada para fazer frente a particularismos, e mesmo a privilégios de dados segmentos sociais mais antigos. Na França, por exemplo, esta unificação é feita pela via legislativa, em outras paragens este tipo de medida é realizada através da recepção do direito romano como direito subsidiário, como na Alemanha.

Igualmente esta sistematização/unificação busca dar maior segurança jurídica às relações. As regras jurídicas foram cada vez mais sendo escritas com o objetivo de assegurar cumprimento posterior. Gradativamente vai suplantando o direito oral vindo este em pouco tempo experimentar uma redução sistemática.

Este processo de emergência do direito na modernidade cuida de fazer dos juristas modernos formalistas, por excelência, tornando-os incapazes "de ver a vida de outra maneira senão através dos textos, e só sabendo 'deduzir' a partir dos textos” (VILLEY, 2007, p. 53). Tornando o Direito um saber refém dos textos, se constituirá com o tempo uma atividade de impedimento e de controle da própria interpretação, posto que a atividade interpretativa nunca foi vista sem o olhar da suspeição pelos poderes constituídos.

A racionalidade instrumental moderna não poderia ter condições mais favoráveis para fazer do Direito um saber ideologicamente comprometido com a nova ordem de coisas 
que se afirmava. É com este estado de coisas que se inicia a ruptura moderna no direito, com a mudança de sua função descritiva para sua função prescritiva.

\section{Referências}

BONAVIDES, Paulo. Do Estado Liberal ao Estado Social. 3. ed. Rio de Janeiro: FGV, 1972.

GADAMER, Hans-Georg. Verdade e método I: traços fundamentais de uma hermenêutica filosófica. 5. ed. Petrópolis: Ed. Vozes, 2003.

Verdade e método II: complementos e índice. 2. ed. Petrópolis: Ed. Vozes, 2004.

GALUPPO, Marcelo Campos. Igualdade e diferença: estado democrático de direito a partir do pensamento de Habermas. Belo Horizonte: Mandamentos, 2002.

GILISSEN, John. Introdução histórica ao direito. 4. ed. Lisboa: Fundação Calouste Gulbenkian, 2003.

LIMA, Alceu Amoroso. Introdução ao direito moderno. 4. ed. Rio de Janeiro: Ed. PUC - Rio: Loyola, 2001.

SANTOS, Boaventura de Sousa. A crítica da razão indolente: contra o desperdício da experiência. 6. ed. São Paulo: Cortez, 2007.

VILLEY, Michel. A formação do pensamento jurídico moderno. 1. ed. São Paulo: Martins Fontes, 2005.

O Direito e os Direitos Humanos. 1. ed. São Paulo: Martins Fontes, 2007.

WEYL, Paulo Sérgio. Autonomia e norma jurídica. Porto Alegre: Livraria do Advogado Editora, 2008.

WOLKMER, Antonio Carlos. História do direito no Brasil. 4. ed. Rio de Janeiro: Ed. Forense, 2007. 